\title{
Metal Concentration in Muscle Tissue of Carp and Pike from Different Fish Ponds in Belgrade Area
}

\author{
Jelena Janjić ${ }^{1}$, Jelena Ivanović ${ }^{1}$, Radmila Marković ${ }^{1}$, Marija Starčević ${ }^{1}$, Marija Bošković ${ }^{1}$, Vesna Đorđević ${ }^{2}$ and \\ Milan Baltić ${ }^{1}$ \\ 1. Faculty of Veterinary Medicine, Department of Food Hygiene and Technology, University of Belgrade, Bulevar Oslobodjenja 18, \\ Belgrade 11000, Serbia \\ 2. Institute of Meat Hygiene and Technology, Kaćanskog 13, Belgrade 11000, Serbia
}

\begin{abstract}
This study was conducted to determine the contamination data of some heavy metals in 10 fish tissue samples of two different fish species - common carp and Northern pike from four different fish ponds and to compare the level of contamination and the differences in the concentration of these elements between these two fish species and between compared fish ponds. In various fish ponds, metal concentrations in the carp muscle tissue varied depending on the metal type. Between compared fish ponds, there were significant differences $(P<0.01)$ in the concentration in muscle carp tissue, except for cadmium. Metal concentrations in the pike muscle tissue also varied among fish ponds, depending on the type of metal. In all compared cases, there were significant differences between metal concentration in pike muscle tissue $(P<0.01)$. Lead and cadmium concentration in pike muscle tissue were significantly higher $(P<0.01, P<0.05$, respectively), and mercury and arsenic concentration were significantly lower $(P<$ $0.01)$ than concentration of this heavy metals in carp muscle tissue in all comapered fish ponds. The results obtained in this study indicate variation in a range of examined metal concentration in muscle tissue, which seems to be typical for the Serbian fish ponds, but is lower than those in rivers with considerable anthropogenic impact.
\end{abstract}

Key words: Common carp, fish pond, metal concentration, Northern pike.

\section{Introduction}

Fish is an important part of the human diet, but also a good indicator of environmental contamination by a number of substances, including trace metals in freshwater systems, notably because fish are at the top of the food chain in the water ecosystem [1]. Much attention has been paid to hazardous elements, such as lead $(\mathrm{Pb})$, cadmium $(\mathrm{Cd})$, mercury $(\mathrm{Hg})$ and arsenic (As), and the effects of exposure to these elements have been comprehensively studied [2-4]. Indeed, due to their toxicity, persistence and bioaccumulation in water and sediment, when occurring in high concentrations, these elements become severe poisonous for all living organisms. In terms of public health food safety, $\mathrm{Pb}, \mathrm{Cd}$ and $\mathrm{Hg}$ are monitored in fish with the maximum levels of heavy metals in

Corresponding author: Jelena Janjić, Ph.D., research fields: food safety and food quality. foodstuffs fixed by Commission Regulation (EC) No. 1881/2006 [5] amended by EC 629/2008 [6]. For As, no maximum level has yet been established at European level, but discussions are ongoing on this topic, and it is anticipated that limits will be set for As in the near future, as the methodology for the determination of As and its speciation improves [1].

In aquaculture, management practices, such as supplementary feeding or fertilisation of water, are generally considered to improve fish yield in water bodies. Nevertheless, in semi-natural systems where many water bodies are situated in a cultural landscape, this is much less evident for certain fish farmers, because fish production systems are often quite extensive, and fish production is only one economic activity among others for these fish farmers [7].

Although many studies have examined the relationship between metal exposure, accumulation 
and toxicity under laboratory conditions, prediction of toxic effects based on environmental or tissue concentrations remains difficult under natural exposure conditions $[8,9]$. Data from the literature indicated that the contents of these elements in fish varied as a function of the different localities, but depended on species and feeding behaviour and also various biotic and abiotic factors, such as, fish biological habitat, as well as by fish weight and body length (evaluated from the condition factor), fish age, gender, physiological conditions, spawning status or migration, even in the same area $[1,8,10-14]$.

This study was undertaken to determine the contamination data of $\mathrm{Pb}, \mathrm{Cd}, \mathrm{Hg}$ and $\mathrm{As}$ in the muscle of two fish species (common carp-Cyprinus carpio and Northern pike-Esox lucius) from four different fish ponds and to compare the level of contamination and the differences in the concentration of these elements between these two fish species and between compared fish ponds.

\section{Materials and Methods}

To determine heavy metals in 10 fish tissue samples of two different fish species - common carp (Cyprinus carpio) and Northern pike (Esox lucius) were collected. The samples were caught by professional fishermen during early autumn of 2013 from four different fishponds in Belgrade area. All individuals were identified to species level, and a random sub-sample of 10 individuals per species at each location was used for metal analysis. Fish were dissected, and samples of muscle (ca. $200 \mathrm{~g}$ ) below the dorsal were stored for metal analyses in polypropylene vials previously pre-cleaned with nitric acid $(10 \%)$ and rinsed three times in water. Muscle was selected to determine the risk posed by metal pollution to humans [15]. The total weight $(\mathrm{g})$ of fishes was measured and transported in refrigerator at $5{ }^{\circ} \mathrm{C}$ daily to the laboratory. The samples were dissected to obtain muscle samples, then were mixed homogeneously and immediately frozen and stored at $-20{ }^{\circ} \mathrm{C}$.

The analysis was performed by the assessment of concentrations of the following elements: As, $\mathrm{Al}, \mathrm{Zn}$, $\mathrm{Fe}, \mathrm{Cu}, \mathrm{As}, \mathrm{Sd}, \mathrm{Hd}$ and $\mathrm{Pb}$. The concentrations in fish meat (i.e., muscle samples) were also recalculated to the wet tissue weight (ww) and compared with the maximum allowed concentrations (MAC) in fish meat for the utilization in human diet, as established by the Europea Union (EU) and the national legislation. According to the EU legislation [6], the MAC for $\mathrm{Cd}$, $\mathrm{Hg}$ and $\mathrm{Pb}$ are $0.05,0.05$ and $0.30 \mu \mathrm{g} / \mathrm{g} \mathrm{ww}$, respectively. The national legislation prescribed MAC for $\mathrm{As}, \mathrm{Cd}, \mathrm{Hg}, \mathrm{Pb}, \mathrm{Cu}, \mathrm{Fe}$ and $\mathrm{Zn}$ in fish meat at 2.0, $0.1,0.5,1.0,30.00,30.00$ and $100.00 \mu \mathrm{g} / \mathrm{g} \mathrm{ww}$, respectively [16].

All samples were collected and analyzed in duplicate and the results are expressed as the means \pm standard deviation (SD). Statistical analysis of the results was elaborated using software GraphPad Prism version 5.00 for Windows, GraphPad Software, San Diego California USA ${ }^{1}$. The statistical analysis was performed using student's $t$-test and analysis of variance (ANOVA) with the multiple comparison Turkey's test to determine the significant differences between means, and the significant level of 0.01 and 0.05 was applied.

\section{Results}

Concentrations of different metals in carp muscle tissue from four different fish ponds are shown in Table 1 . The $\mathrm{Pb}$ concentration in carp muscle tissue from fishpond $\mathrm{C}$ was significantly higher $(P<0.01)$ than that from other fish ponds. In various fishponds, metal concentration varied depending on the type of metal. Thus, $\mathrm{Hg}$ concentration in carp muscle tissue from fishpond $\mathrm{C}$ was significantly higher $(P<0.01)$ than that from other fish ponds. Also, $\mathrm{Hg}$ concentration in carp muscle tissue from fishpond A was significantly higher $(P<0.01)$ than that from

\footnotetext{
${ }^{1}$ www.graphpad.com.
} 
fishpond D. Completely different results were obtained for As concentration in carp fishponds. In carp fish pond D, As concentration in muscle tissue of fish was significantly lower $(P<0.01)$ than that from other fish ponds. Also, the As concentration in carp muscle tissue from fishpond $\mathrm{C}$ was significantly higher $(P<0.01)$ than that from fishpond B. There were no significant differences between $\mathrm{Cd}$ concentrations in carp muscle tissue from compared fishponds.

Metal concentration in pike muscle tissue differed from the fishpond, depending on the type of metal. The $\mathrm{Pb}$ concentration in pike muscle tissue from fishpond D was significantly lower $(P<0.01)$ than that from other fish ponds. Also, the $\mathrm{Pb}$ concentration in pike muscle tissue from fishpond $\mathrm{A}$ was significantly higher $(P<0.01)$ than that from fish pond $\mathrm{B}$. The $\mathrm{Cd}$ concentration of muscle tissue in pike was the highest in fish pond $\mathrm{C}$, and it was significantly higher $(P<0.01)$ than that from other fish ponds. The muscle tissue of pike from fishpond $\mathrm{A}$ has significantly higher $(P<0.01) \mathrm{Cd}$ concentration than that from fishpond D. A similar situation was observed with a concentration of $\mathrm{Hg}$ in muscle tissue of pike, which was significantly higher $(P<0.01)$ in the fish pond $\mathrm{C}$ compared to other fish ponds. The $\mathrm{Hg}$ concentration in pike muscle tissue from fishpond $\mathrm{D}$ was significantly lower $(P<0.01)$ than that from fishpond $\mathrm{A}$ and $\mathrm{B}$. The As concentration in pike muscle tissue was also significantly higher $(P<0.01)$ in fish pond $\mathrm{C}$ than that from other fish ponds (Table 2).

The $\mathrm{Pb}$ concentration in muscle tissue of pike from all observed fish ponds was significantly higher $(P<$ $0.01)$ than the $\mathrm{Pb}$ concentration in carp muscle tissue (Fig. 1).

The $\mathrm{Cd}$ concentration in pike muscle tissue was significantly higher $(P<0.01)$ than the $\mathrm{Cd}$ concentration in the carp muscle tissue of all compared fish carps (Fig. 2).

As opposed to concentration of $\mathrm{Pb}$ and $\mathrm{Cd}$, the $\mathrm{Hg}$ concentration in muscle tissue of pike from all observed fish ponds was significantly lower $(P<0.01)$ than the $\mathrm{Hg}$ concentration in carp muscle tissue (Fig. 3).

The As concentration was significantly higher $(P<$ $0.01)$ in carp muscle tissue than the As concentration in pike muscle tissue (Fig. 4).

Table 1 Metal concentration in carp muscle tissue.

\begin{tabular}{lllll}
\hline \multirow{2}{*}{ Fishpond } & \multicolumn{4}{c}{ Metal concentration $(\mu \mathrm{g} / \mathrm{g})$} \\
\cline { 2 - 5 } & $\mathrm{Pb}$ & $\mathrm{Cd}$ & $\mathrm{Hg}$ & $\mathrm{As}$ \\
\cline { 2 - 5 } & $0.0189^{\mathrm{A}} \pm 0.0031$ & $0.067 \pm 0.0038$ & $0.401^{\mathrm{A}, \mathrm{B}} \pm 0.0105$ & $0.353^{\mathrm{A}} \pm 0.0256$ \\
$\mathrm{~A}$ & $0.0186^{\mathrm{B}} \pm 0.0039$ & $0.061 \pm 0.0038$ & $0.393^{\mathrm{C}} \pm 0.0111$ & $0.343^{\mathrm{B}, \mathrm{C}} \pm 0.0267$ \\
$\mathrm{~B}$ & $0.0301^{\mathrm{A}, \mathrm{B}, \mathrm{C}} \pm 0.0043$ & $0.065 \pm 0.0043$ & $0.485^{\mathrm{A}, \mathrm{C}, \mathrm{D}} \pm 0.0082$ & $0.378^{\mathrm{B}, \mathrm{D}} \pm 0.0085$ \\
$\mathrm{C}$ & $0.0204^{\mathrm{C}} \pm 0.0017$ & $0.058 \pm 0.0145$ & $0.387^{\mathrm{B}, \mathrm{D}} \pm 0.0063$ & $0.252^{\mathrm{A}, \mathrm{C}, \mathrm{D}} \pm 0.0040$ \\
$\mathrm{D}$ & &
\end{tabular}

${ }^{\text {A-D }}$ Means with the same superscript letter in a column are significantly different at $P<0.01$.

Table 2 Metal concentration in pike muscle tissue.

\begin{tabular}{lllll}
\hline \multirow{2}{*}{ Fishpond } & \multicolumn{4}{c}{ Metal Concentration $(\mu \mathrm{g} / \mathrm{g})$} \\
\cline { 2 - 5 } & $\mathrm{Pb}$ & $\mathrm{Cd}$ & \multicolumn{4}{c}{$\mathrm{Hg}$} & $\mathrm{As}$ \\
\cline { 2 - 5 } & & & \multicolumn{4}{c}{ Mean $\pm \mathrm{SD}$} & $0.224^{\mathrm{A}, \mathrm{B}, \mathrm{C}} \pm 0.0096$ \\
$\mathrm{~A}$ & $0.069^{\mathrm{A}, \mathrm{B}} \pm 0.0031$ & $0.071^{\mathrm{A}, \mathrm{B}} \pm 0.0031$ & $0.294^{\mathrm{A}, \mathrm{B}} \pm 0.0058$ & $0.206^{\mathrm{A}, \mathrm{D}, \mathrm{E}} \pm 0.0087$ \\
$\mathrm{~B}$ & $0.063^{\mathrm{A}, \mathrm{C}} \pm 0.0039$ & $0.067^{\mathrm{C}} \pm 0.0030$ & $0.289^{\mathrm{C}, \mathrm{D}} \pm 0.0067$ & $0,249^{\mathrm{B}, \mathrm{D}, \mathrm{F}} \pm 0.0068$ \\
$\mathrm{C}$ & $0.065^{\mathrm{D}} \pm 0.0014$ & $0.079^{\mathrm{A}, \mathrm{C}, \mathrm{D}} \pm 0.0046$ & $0.313^{\mathrm{A}, \mathrm{C}, \mathrm{E}} \pm 0.0064$ & $0.159^{\mathrm{C}, \mathrm{E}, \mathrm{F}_{ \pm} \pm 0.0074}$ \\
$\mathrm{D}$ & $0.057^{\mathrm{B}, \mathrm{C}, \mathrm{D}} \pm 0.0006$ & $0.063^{\mathrm{B}, \mathrm{D}} \pm 0.0045$ & $0.217^{\mathrm{B}, \mathrm{D}, \mathrm{E}} \pm 0.0048$ & \\
\hline
\end{tabular}

${ }^{\mathrm{A}-\mathrm{F}}$ Means with the same superscript letter in a column are significantly different at $P<0.01$. 


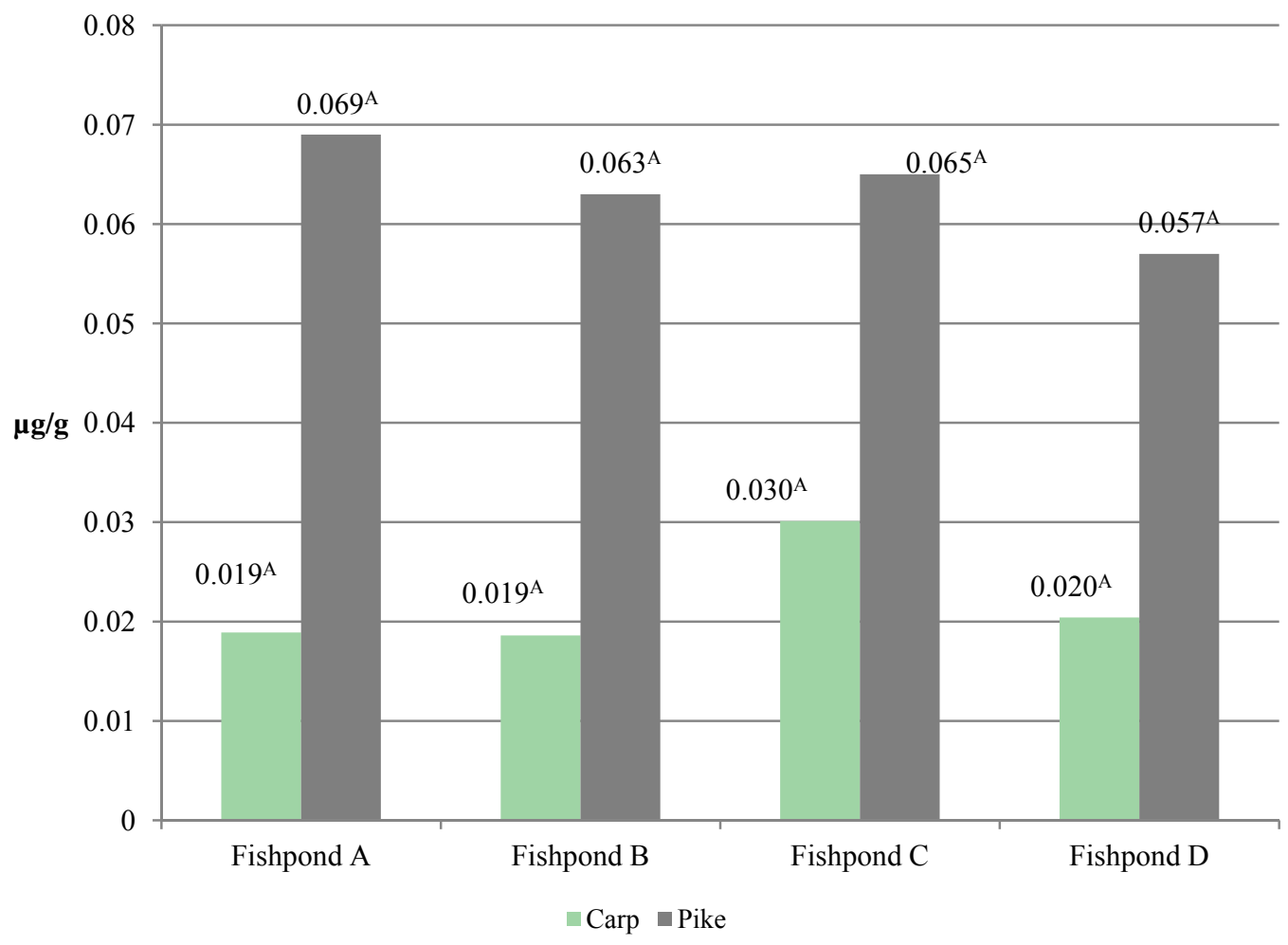

Fig. 1 Pb concentration in carp and pike muscle tissue.

Same letter A means the significant difference at $P<0.01$.

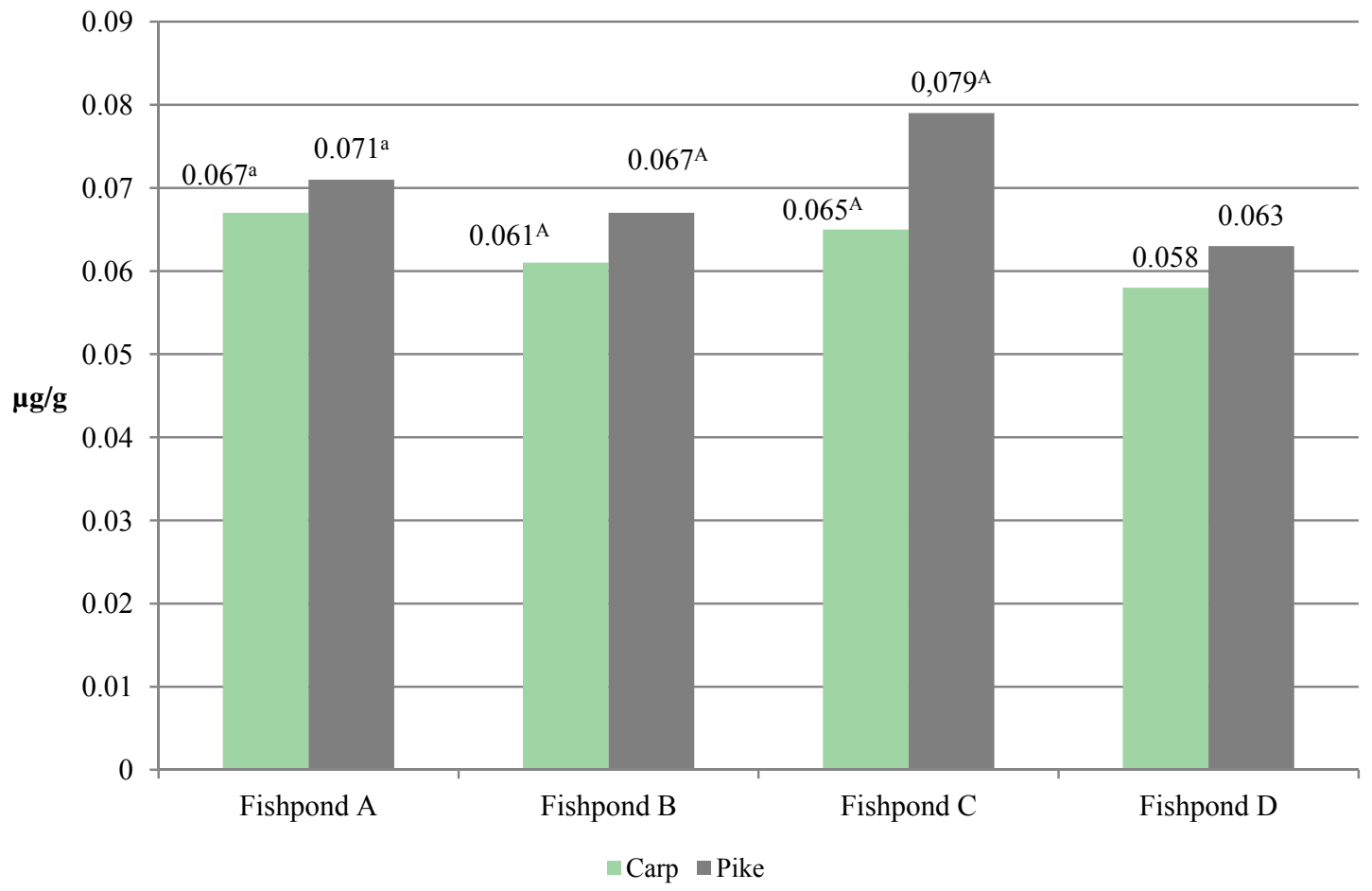

Fig. 2 Cd concentration in carp and pike muscle tissue.

Same letter A means the significant difference at $P<0.01$; same letter a means the significant difference at $P<0.05$. 


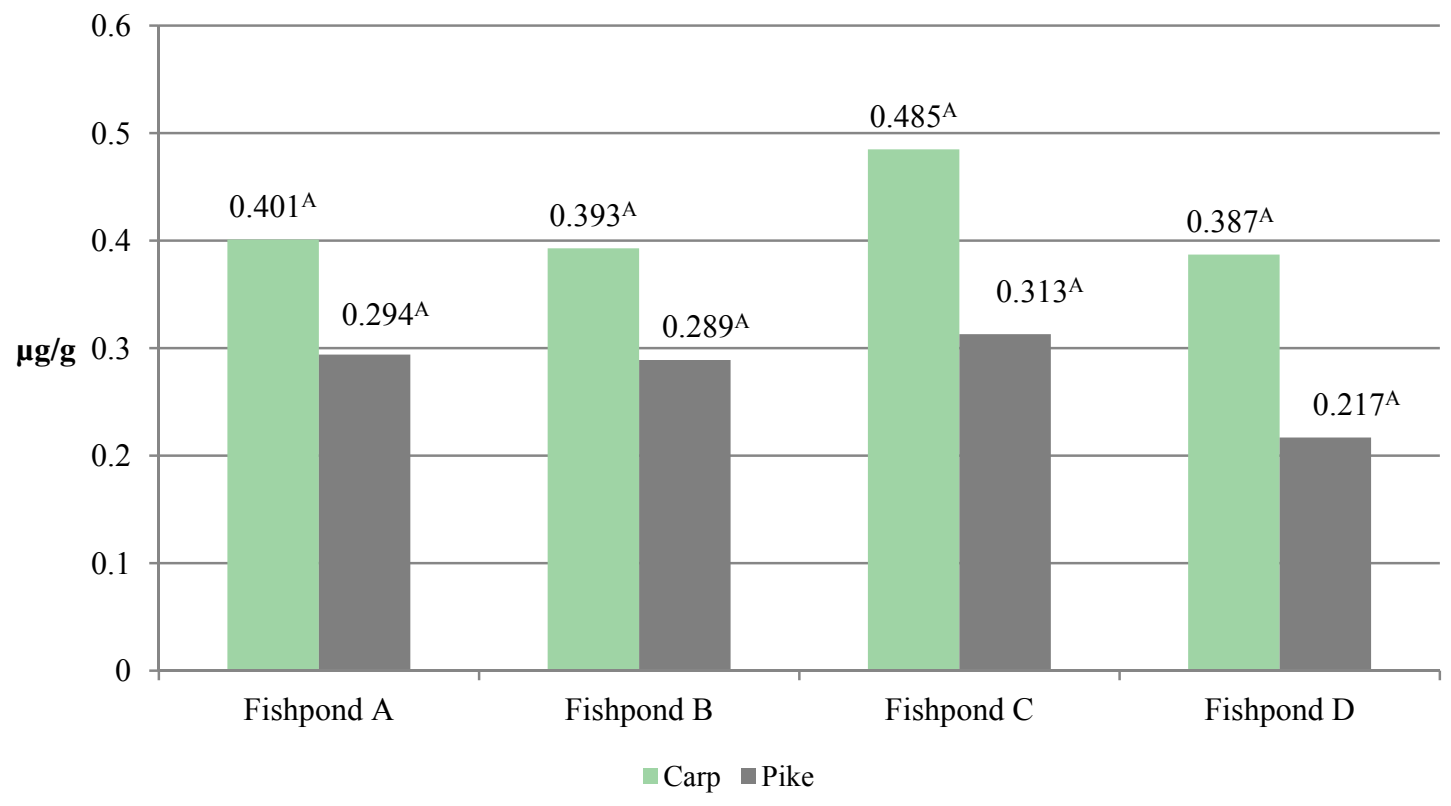

Fig. 3 Hg concentration in carp and pike muscle tissue.

Same letter A means the significant difference at $P<0.01$.

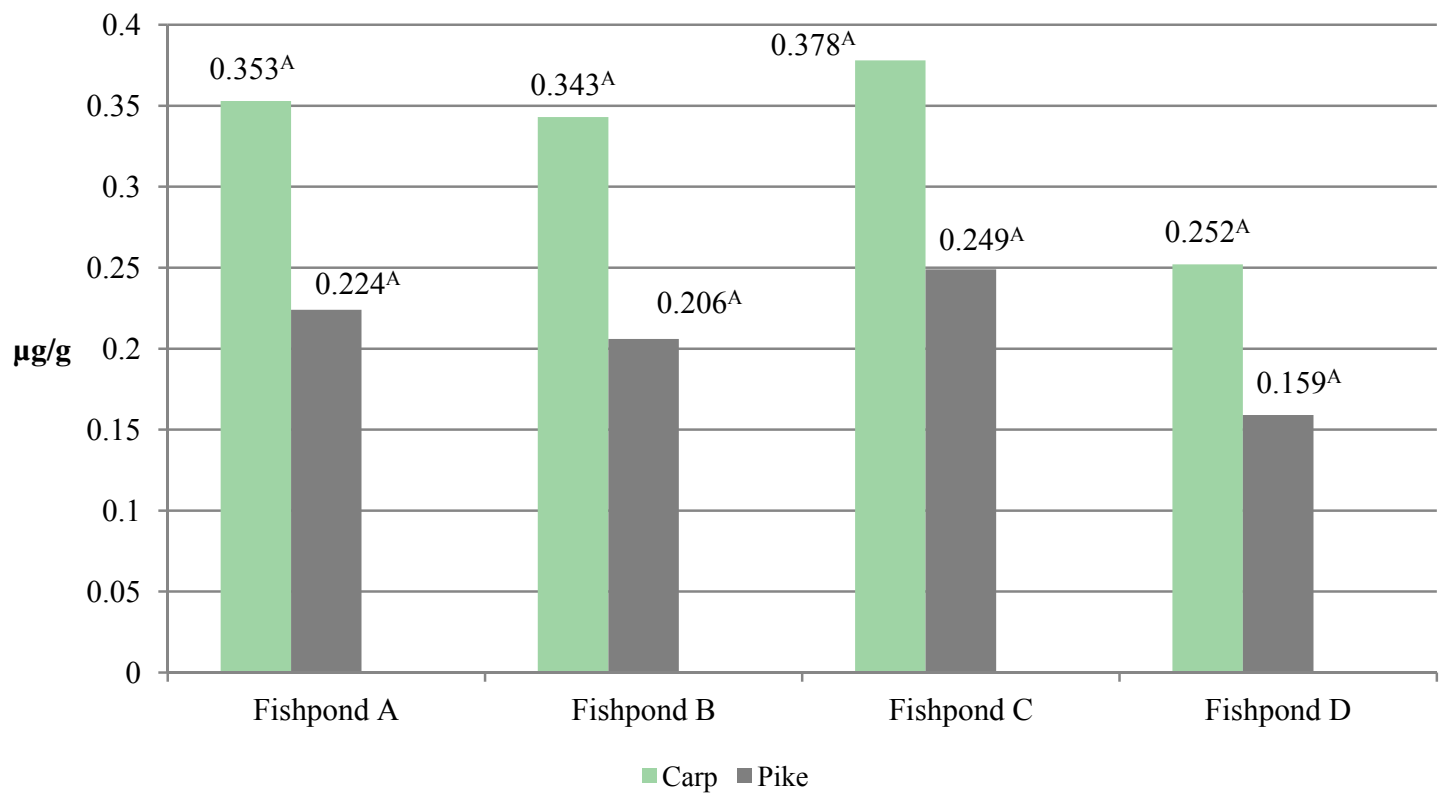

Fig. 4 As concentration in carp and pike muscle tissue.

Same letter A means the significant difference at $P<0.01$.

\section{Discussion}

Knowledge aboout heavy metal concentrations in fish is important both with respect to nature management and human health. The toxicity of metal most commonly involves the brain and the kidney, but other manifestations occur, and some metals are clearly capable of causing cancer. An individual with metals toxicity, even if high dose and acute, typically has very general symptoms, such as weakness or headache [17].

The accumulation of pollutants in organisms includes complex processes controlled by different endogenous and exogenous factors. Exogenous factors 
reflect environmental parameters, such as metal speciation or $\mathrm{pH}$, temperature and alkalinity of ambient aquatic surroundings, whereas endogenous factors include species, age, size, physiological state and type of feeding. Mean concentrations of heavy metals in muscle tissue of two different fish species showed great variations. Statistical comparisons revealed that metal concentrations in muscle tissue were significantly different in each fish ponds.

$\mathrm{Pb}$ concentrations in carp tissues were lower than MAC [6], and the authors found the significant differences in concentration between different fish ponds, and the same results were reported by Čelechovská et al. [18].

Cd distribution in muscle tissues is shown in Fig. 2. Significantly differences were found between $\mathrm{Cd}$ concentration in different fish ponds (A, B, C, D). Due to a very long elimination half-life, $\mathrm{Cd}$ gets accumulated in muscle tissues [19]. Cd concentrations in carp and pike muscle tissue were higher than MAC, according to EU legislation [6] (Fig. 2). The same results were reported by different authors from their experimental $\mathrm{Cd}$ contamination laboratory studies [20-22].

$\mathrm{Hg}$ is a highly toxic and the most closely monitored contaminant in fish [18]. Four homogeneous groups (A, B, C, D) of $\mathrm{Hg}$ concentrations were found at the $P$ $<0.05$ level of significance. $\mathrm{Hg}$ concentrations of carp and pike fish are given in Fig. 3. Because of its cycle in nature, $\mathrm{Hg}$ remains a topical issue. From the hygienic point of view, $\mathrm{Hg}$ concentrations found in carp and pike muscle tissue were lower than MAC [6]. The same results were reported by Čelechovská et al. [18]. Also, significant differences were found between $\mathrm{Hg}$ concentration in muscle tissue of carp and pike from different fish pond.

As distribution in fish muscle tissues from four different fish ponds (A, B, C, D) were significantly different $(P<0.01)$. The highest As concentrations were found in muscle tissue from carp in $\mathrm{C}$ fish ponds $(0.378 \mu \mathrm{g} / \mathrm{g})$. As concentrations in muscle tissue were lower than MAC [15]. The same results were reported by Čelechovská et al. (median $0.086 \mathrm{mg} / \mathrm{kg}$, mean $0.092 \mathrm{mg} / \mathrm{kg}$ ) [18].

In this research, high levels of $\mathrm{Zn}, \mathrm{Cd}$ and $\mathrm{Pb}$ concentrations were measured for human consumption in some seasons. The general body of the literature on $\mathrm{Pb}$ toxicity indicates that, depending on the dose, $\mathrm{Pb}$ exposure in children and adults can cause a wide spectrum of health problems, ranging from convulsions, coma, renal failure and death at the high end to subtle effects on metabolism and intelligence at the low end exposures [23]. In contrast to children, adults are generally allowed by regulations to be exposed to higher amounts of $\mathrm{Pb}$. The health implications of $\mathrm{Cd}$ exposure are exacerbated by the relative inability of human beings to excrete $\mathrm{Cd}$. Acute high dose exposures can cause severe respiratory irritation. The occupational levels of $\mathrm{Cd}$ exposure prove to be a risk factor for chronic lung disease and testicular degeneration [24, 25].

\section{Conclusions}

This study provides information about heavy metals content in muscle tissue of carp and pike from four fish ponds. Analysis of carp and pike muscle tissue showed higher concentration of Cd than MAC, but other heavy metals $(\mathrm{Pb})$ in the same samples were under levels of EU legislation. Metal concentration in the muscle tissue of carp and pike varied considerably between the examined fish ponds. The results for the four elements in fish muscle show variation in a range, which seems to be typical for the Serbian fish ponds, but is lower than those in rivers with considerable anthropogenic impact.

\section{Acknowledgments}

The authors thank for the support by the Ministry of Education and Science, Republic of Serbia, Project "selected biological hazards to the safety/quality of food of animal origin and the control measures from farm to consumer" (31034). 


\section{References}

[1] Noël, L., Chekri, R., Millour, S., Merlo, M., Leblanc, J. C., and Guérin, T. 2013. "Distribution and Relationships of $\mathrm{As}, \mathrm{Cd}, \mathrm{Pb}$ and $\mathrm{Hg}$ in Freshwater Fish from Five French Fishing Areas." Chemosphere 90 (6): 1900-10.

[2] Castro-González, M. I., and Méndez-Armenta, M. 2008. "Heavy Metals: Implications Associated to Fish Consumption." Environmental Toxicology and Pharmacology 26 (3): 263-71.

[3] Has-Schön, E., Bogut, I., and Strelec, I. 2006. "Heavy Metal Profile in Five Fish Species Included in Human Diet, Domiciled in the End Flow of River Neretva (Croatia)." Archives of Environmental Contamination and Toxicology 50 (4): 545-51.

[4] Storelli, M. M. 2008. "Potential Human Health Risks from Metals $(\mathrm{Hg}, \mathrm{Cd}$ and $\mathrm{Pb})$ and Polychlorinated Biphenyls (PCBs) via Seafood Consumption: Estimation of Target Hazard Quotients (THQs) and Toxic Equivalents (TEQs)." Food and Chemical Toxicology 46 (8): 2782-8.

[5] Commission Regulation (EC). 2006. "Commission Regulation (EC) No. 1881/2006 of 19 December 2006 Setting Maximum Levels for Certain Contaminants in Foodstuffs." Official Journal of the European Union L364, 0005-0024. Accessed December 19, 2006. http://eur-lex.europa.eu/LexUriServ/LexUriServ.do?uri= OJ:L:2006:364:0005:0024:EN:PDF.

[6] Commission Regulation (EC). 2008. "Commission Regulation (EC) No 629/2008 of 2 July 2008 Amending Regulation (EC) No. 1881/2006 Setting Maximum Levels for Certain Contaminants in Foodstuffs." Official Journal of the European Union L173, 0006-0009. Accessed July 2, 2008. http://eur-lex.europa.eu/LexUriServ/LexUriServ.do? uri=OJ:L:2008:173:0006:0009:EN:PDF.

[7] Skorić, S., Visnjić-Jeftić, Ž., Jaric, I., Djikanović, V., Micković, B., Nikcević, M., and Lenhardt, M. 2012. "Accumulation of 20 Elements in Great Cormorant (Phalacrocorax carbo) and Its Main Prey, Common Carp (Cyprinus carpio) and Prussian Carp (Carassius gibelio)." Ecotoxicology and Environmental Safety 80: 244-51.

[8] Peakall, D., and Burger, J. 2003. "Methodologies for Assessing Exposure to Metals: Speciation, Bioavailability of Metals and Ecological Host Factors.” Ecotoxicology and Environmental Safety 56 (1): 110-21.

[9] Višnjić-Jeftić, Ž., Jarić, I., Jovanović, L., Skorić, S., Smederevac-Lalić, M., Nikčević, M., and Lenhardt, M. 2010. "Heavy Metal and Trace Element Accumulation in Muscle, Liver and Gills of the Pontic Shad (Alosa immaculata Bennet 1835) from the Danube River (Serbia).” Microchemical Journal 95 (2): 341-4.

[10] Berninger, K., and Pennanen, J. 1995. "Heavy Metals in
Perch (Perca fluviatilis L.) from Two Acidified Lakes in the Salpausselka Esker Area in Finland." Water Air and Soil Pollution 81 (3): 283-94.

[11] Andres, S., Ribeyre, F., Tourencq, J. N., and Boudou, A. 2000. "Interspecific Comparison of $\mathrm{Cd}$ and Zinc Contamination in the Organs of Four Fish Species along a Polymetallic Pollution Gradient (Lot River, France)." Science of the Total Environment 248 (1): 11-25.

[12] Canli, M., and Atli, G. 2003. "The Relationships between Heavy Metal (Cd, Cr, Cu, Fe, Pb, Zn) Levels and the Size of Six Mediterranean Fish Species." Environmental Politics 121 (1): 129-36.

[13] Farkas, A., Salánki, J., and Specziár, A. 2003. "Age- and Size-Specific Patterns of Heavy Metals in the Organs of Freshwater Fish Abramis brama L. Populating a Low Contaminated Site." Water Research 37 (5): 959-64.

[14] Has-Schön, E., Bogut, I., Rajković, V., Bogut, S., Čačić, M., and Horvatić, J. 2008. "Heavy Metal Distribution in Tissues of Six Fish Species Included in Human Diet, Inhabiting Freshwaters of the Nature Park 'Hutovo Blato' (Bosnia and Herzegovina)." Archives of Environmental Contamination and Toxicology 54 (1): 75-83.

[15] Miller, P. A., Munkittrick, K. R., and Dixon, D. G. 1992. "Relationship between Concentrations of Copper and Zinc in Water, Sediment, Benthic Invertebrates and Tissues of White Sucker (Catastomus commersoni)." Canadian Journal of Fisheries and Aquatic Sciences 49 (5): 978-84.

[16] Official Gazzette of RS. 2011. "Regulation on Quantity of Pesticides, Metals, Metalloids and Other Toxic Substances, Chemotherapeutics, Anabolics and Other Substances Which Can Be Found in Food." Official Gazzette of RS, No. 28/2011. Accessed April 26, 2011. http://www.mooshema.com/wp-content/uploads/2013/02/ Pravilnik-o-dopuni-Pravilnika-o-maks.dozvolj.koli_inam a-ostataka-sredstava-za-za_titu-bilja-u-hrani-i-hrani-za-_i votinje-Sl.-glasnik-RS-br.-28-2011.pdf.

[17] Dural, M., Goksu, M. Z. L., and Ozak, A. A. 2007. "Investigation of Heavy Metal Levels in Economically Important Fish Species Captured from the Tuzla Lagoon." Food Chemistry 102 (1): 415-21.

[18] Čelechovská, O., Svobodová, Z., Žlábek, V., and Macharáčková, B. 2007. "Distribution of Metals in Tissues of the Common Carp (Cyprinus carpio L.)." Acta Veterinaria Brno 76 (8): 93-100.

[19] Cornelis, R., Caruso, J., Crews, H., and Heumann, K. 2005. Handbook of Elemental Speciacion II-Species in the Environment, Food, Medicine and Occupational Health. Chichester, England: Wiley, 768.

[20] Paláčková, J., Pravda, D., Fašaic, K., and Čelechovská, O. 1994. "Sublethal Effects of Cadmium on Carp (Cyprinus carpio) Fingerlings." In Sublethal and Chronic Effects of 
Pollutants on Freshwater Fish, edited by Muller, R., and Lloyd, R. London: Blackwell Science, 53-61.

[21] Drastichová, J., Svobodová, Z., Lusková, V., Čelechovská, O., and Kaláb, P. 2004. "Effect of Cadmium on Blood Plasma Biochemistry in Carp (Cyprinus carpio L.)." Bulletin of Environmental Contamination and Toxicology 72 (4): 733-40.

[22] Reynders, H., Van Campenhout, K., Bervoets, L., De Coen, W. M., and Blust, R. 2006. "Dynamics of Cadmium Accumulation and Effects in Common Carp (Cyprinus carpio) during Simultaneous Exposure to Water and Food (Tubifex tubifex)." Environmental
Toxicology Chemistry 25 (6): 1558-67.

[23] US Agency for Toxic Substances \& Disease Registry (ATSDR). 1999. Toxicological Profile for Mercury. Atlanta: US Department of Health and Human Services, Public Health Service, 676.

[24] Benoff, S., Jacob, A., and Hurley, R. I. 2000. "Male Infertility and Environmental Exposure to Lead and Cadmium." Human Reproduction Update 6 (2): 107-21.

[25] Satarug, S., Haswell-Elkins, R. M., and Moore, R. M. 2000. "Safe Levels of Cadmium Intake to Prevent Renal Toxicity in Human Subjects." British Journal of Nutrition 84 (6): 791-802. 